\title{
«ЦІНА-ЯКІСТЬ» В СИСТЕМІ ОРГАНІЗАЦІї ПЕРЕВЕЗЕНЬ ПАСАЖИРІВ АВТОТРАНСПОРТНИМИ ПІДПРИЕМСТВАМИ
}

\section{"TARIFF-QUALITY" IN THE SYSTEM OF ORGANIZATION OF PASSENGER TRANSPORTATION BY ROAD TRANSPORT ENTERPRISES}

\author{
Богомолова Надія Іванівна \\ доктор економічних наук, професор, \\ Державний університет інфрраструктури та технологій \\ ORCID: https://orcid.org/0000-0001-5376-2437 \\ Bohomolova Nadiia \\ State University of Infrastructure and Technology
}

\begin{abstract}
Стаття присвячена аналізу концепції «ціна-якість» в системі тарифоутворення на пасажирські перевезення підприємствами автомобільного транспорту. При використанні витратних, ринкових та змішаних методів ціноутворення доцільно враховувати вплив зміни якості транспортного обслуговування як на витрати автотранспортних підприємств, так і на процес фрормування цінності у споживачів. Розглянуто економічні особливості організації пасажирських перевезень автотранспортними підприємствами. Висвітлено основні чинники, що впливають на якість та ефективність таких перевезень. Обґрунтовано структуру економічного механізме фрормування пасажирських автотранспортних тарифрів. Практичне значення дослідження полягає у можливості використання його для фрормування стратегії розвитку автотранспортних підприємств.
\end{abstract}

Ключові слова: підприємства автомобільного транспорту, пасажирські перевезення, тариф, якість, механізм, ефективність.

Статья посвящена анализу концепции «цена-качество» в системе тарифообразования на пассажирские перевозки предприятиями автомобильного транспорта. При использовании затратных, рыночных и смешанных методов ценообразования нужно учитывать влияние изменения качества транспортного обслуживания как на расходы автотранспортных предприятий, так и на формирование ценности у потребителей. Рассмотрены экономические особенности организации пассажирских перевозок автотранспортными предприятиями. Отражены основные фракторы, влияющие на качество и эфреективность таких перевозок. Обоснована структура экономического механизма формирования пассажирских автотранспортных тарифов. Практическое значение исследования состоит в возможности его использования для формирования стратегии развития автотранспортных предприятий.

Ключевые слова: предприятия автомобильного транспорта, пассажирские перевозки, тарифр, качество, механизм, эфрфективность.

The relevance of the topic of the article is due to the lack of validity of approaches to tariff-setting for passenger road transportation. The purpose of the article is to analyze the concept of "tariff-quality" in the system of organization of passenger road transportation. In preparing the article, methods of logical generalization and critical analysis of research results are used, as well as a systematic approach to the analysis of factors influencing the tariff-setting process in the field of passenger road transportation. Tariff-setting is one of the important factors in the organization and provision of passenger road transportation. The scientifically substantiated tariff-setting for passenger transportation is a complex procedure for establishing the feasibility and further application of methods and techniques. This allows to set a fair tariff. This helps to balance the economic interests of transport participants and stimulate demand for transportation. Scientific and economic substantiation of the tariffs' level is often based on the use of cost or market pricing methods or a combination thereof. At the same time, it is advisable when using these methods to consider the impact of changes in the quality of transport services on the costs of road enterprises, to investigate tariffs from competitors, as well as the process of value formation for users of transport and related services. The article considers the economic features of the organization of passenger transportation by road enterprises. The main factors influencing the quality and efficiency of such a process are highlighted. The economic mechanism of passenger tariff-setting is substantiated. In the structure of the mechanism there are functional components - revenue and 
expenditure management systems of road transport enterprises, as well as the main levers and forms of tariff-setting. The practical significance of the submitted materials is the possibility of their use for the formation of financial and economic strategy for the development of road transport enterprises, as substantiated tariffs are important for managing revenues and expenditures of enterprises and affect the efficiency and competitiveness of carriers.

Keywords: road transport enterprises, passenger transportation, tariff, quality, mechanism, efficiency.

Постановка проблеми. Пасажирські перевезення виконують важливу соціально необхідну фрункцію щодо забезпечення потреб людей у переміщенні. Між тим, підприємства різних видів транспорту при організації перевезень вирішують складні задачі з вдосконалення процесу обслуговування пасажирів при достатньо обмежених виробничих ресурсах як для розвитку, так і для поточного фрункціонування. В цих умовах зростає значення виваженої тарифної політики перевізних підприємств, в тому числі й автомобільного транспорту. Тарифри становлять основу фрормування доходної частини економічної діяльності, від їх рівня та відповідності наданій послузі залежить вибір пасажиром того, чи іншого виду транспорту. Між тим, на сьогодні залишаються недостатньо обґрунтованими підходи до орормування тарисрів на пасажирські перевезення автомобільним транспортом, а наявний економічний інструментарій вимагає перегляду з урахуванням зміни умов ринкового фрункціонування.

Крім того, удосконалення тарифноої політики на пасажирські перевезення як важливий напрям підвищення ефрективності та конкурентоспроможності перевізників задекларований в Національній транспортній стратегії України до 2030 року [1], згідно з якою виважена тарисрна політика може змінити тенденції, коли частина пасажирів замість громадського транспорту переходить до більшого користування власними автотранспортними засобами, що в цілому негативно відбивається і на екології, і на пропускних спроможностях доріг.

Аналіз останніх досліджень і публікацій. Проблеми удосконалення тарифрів на перевезення пасажирів автотранспортними підприємствами стали предметом дослідження таких вчених, як Богаченко М.В., Легкий С.А., Некрасова Л.А., Пилипенко О.М., Савченко Л.А., Сокульський О.Є. та ін. [2-8]. В зазначених публікаціях досліджується можливість удосконалення маркетингових і витратних методів ціноутворення, розглядаються концептуальні засади розвитку автотранспорту та його суб'єктів, зазначається на важливості встановлення реального обсягу пасажиропотоку, що впливатиме на доходні надходження. Між тим, цілісний механізм ціноутворення на пасажирському автотранспорті не сорормовано.

Виділення не вирішених раніше частин загальної проблеми. Проведений аналіз публікацій $з$ питань удосконалення ціноутворення на пасажирські автотранспорті перевезення показав, що не зважаючи на те, що якість транспортних послуг визнається ключовим чинником у фрормуванні справедливої ціни поїздки пасажира, цілісна концепція «ціна-якість» як базис системи ціноутворення в сорері автоперевезень не досліджувалася. Це дозволило виділити невирішені завдання щодо обґрунтування організаційно-економічних умов реалізації концепції «ціна-якість» та фрормування на ії базі економічного механізму встановлення тарифів на пасажирські автотранспортні перевезення.

Формулювання цілей статті (постановка завдання). Метою статті $\epsilon$ аналіз концепції «ціна-якість» в системі організації автотранспортних перевезень пасажирів для різних методів ціноутворення. Досягнення мети базується на дослідженні системи фрормування тарисрів автотранспортних підприємств на пасажирські перевезення, аналізі їх особливостей та обґрунтуванні структури механізму ціноутворення, в основі якого знаходиться якість транспортного обслуговування.

Виклад основного матеріалу дослідження. Встановлення обґрунтованих тарифрів концентрує в собі розуміння специфріки всіх виробничо-економічних процесів пасажирського автотранспорту, процесу формування систем управління його доходами та витратами, репрезентує економічні відносини між учасниками транспортного процесу, в тому числі і стейкхолдерами.

При встановленні пасажирського тарифру доцільним $€$ дослідження ринку транспортних послуг з метою виявлення найважливіших характеристик для кожного їх виду. Можливість та прийняття управлінських рішень щодо удосконалення тих характеристик, які мають більшу цінність у користувача (задовольняють його потреби) має ґрунтуватися на фракторі зростання вартості транспортної послуги внаслідок такого удосконалення та зміни пов'язаних з ним чинників.

При цьому зростання тарифрів у відповідності із зміню якості транспортних послуг обмеж- 
ується недостатньо високим рівнем добробуту населення та тим чинником, що певна частина пасажирських перевезень здійснюється за рахунок бюджетних дотацій внаслідок наявності пільгових категорій населення.

Співвідношення «ціна-якість» як концепція, що враховує взаємозв'язок між зазначеними категоріями, може застосовуватися як при витратному, так і при ринковому підходах до ціноутворення. Вона $€$ ядром загального підходу до фрормування тарифів.

Так, при застосуванні витратного підходу до ціноутворення основна увага приділяється встановленню науково-обґрунтованого рівня витрат і фрормуванні тарифру на їх базі. В цьому випадку підвищення якості транспортних послуг, як правило, забезпечується підвищенням якості виробничих ресурсів, що використовуються, удосконаленням організації перевезень, їх логістики, узгодженістю та координацію окремих ланок транспортування тощо.

При застосуванні ринкового підходу проводиться аналіз цін у конкурентів. Між тим, такий аналіз не проводиться знеособлено, певний тарифр аналізується у відповідності 3 його якісними характеристиками, можливістю задоволення тих чи інших потреб споживача. Досліджується лояльність до зміни тарисру та умов перевезень. Отже, якість, її аналіз, оцінка та планування $€$ неодмінним чинником процесу тарифоотворення в різних фрормах та при використанні різних методів і інструментів.

Необхідно враховувати, що організація перевезень пасажирів автотранспортними підприємствами має ряд особливостей, зумовлених специсрікою перевізних технологій автомобільного транспорту, а також соціально-необхідним характером перевезень і наявністю пільгових перевезень, необхідністю їх дотації з бюджетних джерел (чи інших фрондів суб'єктів, що встановлюють пільгу). Все це значно обмежує можливості тарифного регулювання і вимагає балансування інтересів учасників при поступовому посиленні лібералізації ціноутворення як це було реалізовано в більшості європейських країн.

Якість транспортних послуг пасажирам доцільно аналізувати у відповідності з підходом, що розрізняє якість процесу та якість його результату. Так, якість процесу безпосередньо залежить від надійності пасажирського руху, вчасності прибуття рухомого складу, його коморортності під час поїздки, відсутності технічних збоїв, достатнім рівнем інформаційного забезпечення пасажира, логістизації, ін.

В свою чергу, якість результату $є$ показником, оцінку якому пасажир може дати після завершення поїздки. Це характеристика загальної задоволеності його потреб, відповідності очікуванням, узгодженості якісних і цінових параметрів перевезення. Задоволення рівнем якості кінцевої продукції - важливий чинник для подальшої взаємодії учасників транспортування. Між тим, необхідно досліджувати зворотній зв'язок 3 клієнтом і на предмет його незадоволення поїздкою, оскільки робота над виправленням ситуації, удосконаленням клієнтських якісних позицій сприятиме підвищенню ефективності у всіх учасників.

Основні чинники, що впливають на якість та ефрективність пасажирських автотранспортних перевезень можна представити у вигляді двох груп - техніко-технологічних та організаційно-економічних. Техніко-технологічні чинники враховують сучасність, надійність та продуктивність транспортних та інших технічних засобів, структуру автопарку, його комфрортність, інноваційність, відповідність стандартам і нормативам, пропускну спроможність автомобільних доріг, ін.

До організаційно-економічних відносяться рівень організації планування на підприємстві, наявність стратегії розвитку транспортного бізнесу, використання можливостей реклами, механізмів податкового регулювання, відповідність нормативно-правової бази реаліям господарювання, рівень інфрляції, можливості та умови фрінансування, кредитування, тощо. Недосконалий порядок компенсацій витрат по пільговим перевезенням також виступає важливим організаційно-економічним чинником дестимулюючого характеру (оскільки розмір компенсації не покриває фрактичні збитки). Ще одним де стимулюючим організаційноекономічним чинником $€$ зменшення кількості платоспроможних пасажирів внаслідок нестабільного соціально-економічного середовища нашої країни.

Сукупність техніко-технологічних та організаційно-економічних чинників, їх аналіз в частині управління ними та адаптування до тих, на які вплинути неможливо $є$ важливою частиною економічного механізму ціноутворення на пасажирські перевезення. Окрім впливу фракторів у механізмі відображені основні принципи ціноутворення, дотримання яких дозволить сорормувати тарифну політику більш простою, прозорою та зрозумілою для клієнта.

В економічному механізмі фрормування тарифрів на перевезення пасажирів автотранспортними підприємствами (рис. 1) виділя- 
ється дві зони відповідальності суб'єкта господарювання: (1) система управління доходами автотранспортних підприємств, яка здебільшого залежить від рівня тарифів та обсягів перевезень, що будуть згенеровані при використанні такої тарифної політики перевізника та (2) система управління витратами, що більше корелюється 3 якістю транспортних послуг, - різна якість та комплексність обслуговування пасажирів, як правило, фрормують різні рівні витрат.

Відповідно і ціноутворення, яке ґрунтується на ринковому методі реалізується за рахунок дослідження попиту та цін конкурентів і встановлення такого рівня тариорів, який би враховував і посилював ринкові позиції підприємства на ринку. Ціноутворення, яке Ґрунтується на управлінні витратами, в першу чергу, спрямоване на оптимізацію витрат, встановлення такого їх рівня, який би забезпечив віддачу вкладених ресурсів; такий метод передбачає використання норм рентабельності, ефективності або підвищуючих коефріцієнтів при фрормуванні тарифу.

Водночас, в сучасних умовах жорсткої конкуренції та загостренні чисельних протиріч розвитку автотранспортних підприємств більш доцільно не концентруватися на одній із систем (управління доходами чи витратами), а одночасно приділяти увагу обом системам та їх взаємозв'язку і взаємообумовленості. При цьому концепція «ціна-якість» виступатиме системоутворюючою ланкою, що має вплив на всі елементи систем управління доходами і витратами, враховує їх взаємовплив.

Система управління доходами АТП містить в собі елементи, спрямовані на ефективне тарифоутворення, це: поелементний аналіз доходів і зв'язок їх з відповідними елементами витратами, оцінка доходності окремих напрямів і маршрутів перевезень, аналіз фракторів і контроль ефеективності результатів економічної діяльності. В свою чергу, система управління витратами АТП забезпечує аналіз витрачання коштів на пасажирські перевезення окремо по підприємству, напряму чи маршруту сполучення. Сукупність завдань систем управління доходами та витратами дозволяють оцінити результативність перевезень (в тому числі за окремими маршрутами), а також забезпечити вдосконалення процесів нормування, організації обліку і контролю фрінансових результатів від пасажирських перевезень, більш обґрунтовано встановити

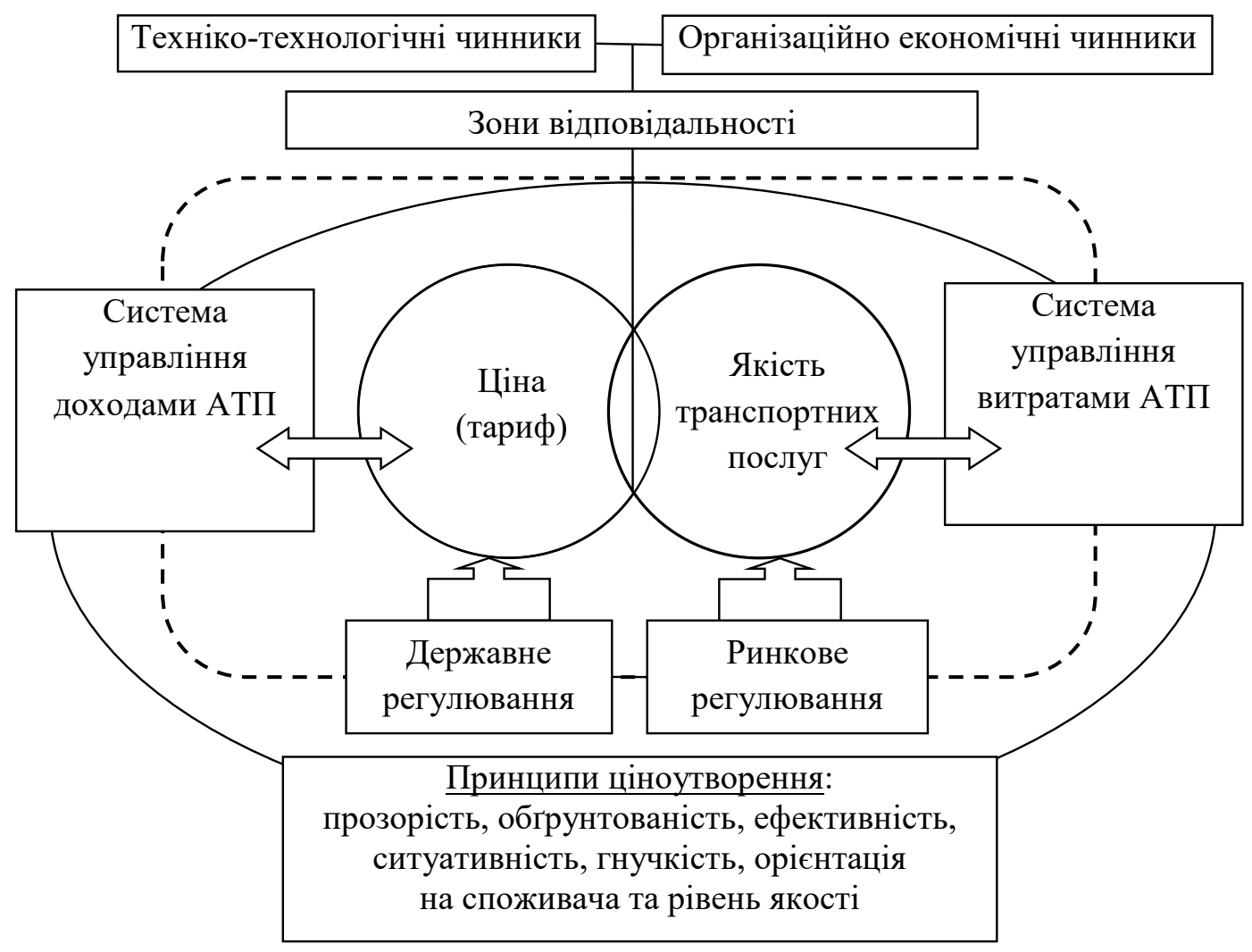

Рис. 1. Структура економічного механізму формування тарифрів на пасажирські перевезення автотранспортними підприємствами (АТП) 
рівень необхідних дотацій (на покриття пільгових перевезень).

Також на користь доцільності об'єднання систем управління витратами і доходами свідчить той фракт, що управління витратами здебільшого враховує ретроспективну інорормацію про аналіз та динаміку витрат (за різними ознаками класифрікації), а управління доходами більш орієнтовано на прогнозування та планування доходів на майбутній період. При поєднанні таких часових орієнтирів вдасться реалізувати тарифну модель, що орієнтована на майбутній період при одночасному врахуванні поточної інфрормації щодо ресурсного витрачання та забезпечення фрункціонування.

Механізм фрормування тарифрів окрім ключових елементів - системи управління доходами та витратами включає в собі фрункціональні методи та інструменти ціноутворення. Серед методів доцільно особливу увагу звернути на використання елементів бюджетування, фрункціонально-вартісного аналізу, ABC-аналізу, SWOT-аналізу; а серед інструментів - планування результатів, забезпечення узгодженості стратегічного бачення та поточної діяльності, збалансування економічних інтересів всіх зацікавлених сторін.

В цілому механізм фрормування тарифів спрямований на подолання протиріч (чи невідповідностей) в організації та управлінні пасажирськими перевезеннями, зокрема, таких протиріч як державне регулювання та потреба в лібералізації ціноутворення на транспортні послуги, протиріччя в економічних інтересах пасажира та перевізника (бажання встановлення більш високого тарифу перевізником і низького споживачем транспортних послуг), iн.

Удосконаленню тарифної політики пасажирських автотранспортних перевезень на основі врахування якості транспортної продукції сприятиме впровадження системи бюджетування та контролінгу витрат і доходів Система управління доходами і витратами має базуватися на систематичній роботі 3 масивами даних щодо обсягів перевезень, якісних характеристик, маркетингових досліджень, фрінансових результатів перевезень, взаємодії з учасникам транспортного ринку, руху грошових потоків, тощо. Контролінг сприяє поєднанню систем управління доходами і витрат, оскільки сприяє вирішенню поточних завдань, але, одночасно, спрямований на перспективний розвиток, підвищення ефективності фрункціонування підприємства за рахунок узгодженості напрямів роботи, показників по видам діяльності, напрямам і окремим маршрутам.

Також особлива увага має бути приділена подальшому впровадженню стандартів надання транспортних послуг, впровадженню міжнародних норм і інструментів організації роботи автотранспортних підприємств, ведення економічної діяльності, розробки стратегічних планів розвитку, в тому числі й фрінансового. Стандартизація повною мірою узгоджується з попереднім завданням щодо застосування контролінгу доходів і витрат, інших параметрів діяльності підприємств.

Висновки. Концепт «ціна-якість» в системі організації перевезень пасажирів на автомобільному транспорті фрормує базис есрективної взаємодії перевізників та пасажирів як споживачів транспортної продукції. Увага узгодженості тарифрів та рівня якості сприяє задоволенню вимог клієнтів щодо прозорості та зрозумілості ціноутворення, що може закласти підґрунтя для довготривалої ефрективної взаємодії всіх учасників транспортного ринку. Формування тарифрів на пасажирські перевезення які ґрунтуються на дослідженні категорії якості транспортних послуг та її впливу на цінність транспортної послуги сприятимуть посиленню конкурентних позицій перевізника.

Подальші дослідження в цьому напрямі доцільно проводити в сорері встановлення впливу окремих чинників якості на тариф, маркетингових досліджень щодо потреби пасажирів в послугах різного рівня якості, а також у використанні інструментів контролінгу витрат і доходів для удосконалення процесу срормування пасажирських тарифрів.

\section{СПИСОК ВИКОРИСТАНИХ ДЖЕРЕЛ:}

1. Національна транспортна стратегія України на період до 2030 року : Розпорядження Кабінету Міністрів України від 30.05.2018 р. № 430-p. URL: https://zakon.rada.gov.ua/laws/show/430-2018-\%D1\%80\#Техt (дата звернення: 15.08.2021).

2. Богаченко М.В. Теоретичні аспекти формування тарифної політики міського пасажирського транспорту. Науковий вісник Ужгородського національного університету. Серія : Міжнародні економічні відносини та світове господарство. 2018. Вип. 19(1). С. 19-22. URL: http://nbuv.gov.ua/UJRN/Nvuumevcg_2018_19(1)_6

3. Богаченко М.В. Світовий досвід організації міського пасажирського транспорту. Бізнес-Навігатор. 2017. Вип. 4-1. С. 21-25. URL: http://nbuv.gov.ua/UJRN/bnav_2017_4-1_6 
4. Легкий С.А. Обґрунтування напрямків маркетингових досліджень при встановленні тарифів на перевезення пасажирів автомобільним транспортом. Економіка транспортного комплексу. 2013. Вип. 22. С. $142-147$. URL: http://nbuv.gov.ua/UJRN/ektk_2013_22_15

5. Некрасова Л.А., Богаченко М.В. Розвиток взаємодії всіх видів транспорту на основі інтегрованої тарифної системи пасажирських перевезень. Причорноморські економічні студії. 2020. Вип. 51. С. $73-79$. URL: http://nbuv.gov.ua/UJRN/bses_2020_51_14

6. Савченко Л.А. Методика розрахунку тарифів на послуги пасажирського автомобільного транспорту. Вісник Національного університету «Львівська політехніка». Динаміка, міцність та проектування машин $і$ приладів. 2017 № 866. С. 230-233. URL: http://nbuv.gov.ua/UJRN/VNULPDM_2017_866_42

7. Сокульський О.Є., Гайдай Г.Г., Васільцова Н.М. Економіко-математичне моделювання при визначенні тарифу пасажирських перевезень на маршрутах із урахуванням якості обслуговування пасажирів. Управління проектами, системний аналіз і логістика. 2014. Вип. 13. С. 125-132. URL: http://nbuv.gov.ua/UJRN/ Upsal_2014_13\%282\%29_15

8. Пилипенко О.М., Огій О.В. Обґрунтування тарифу на перевезення пасажирів автобусним транспортом у м. Черкаси. Вісник Черкаського державного технологічного університету. Серія : Технічні науки. 2018. № 2. C. 20-25. URL: http://nbuv.gov.ua/UJRN/Vchdtu_2018_2_5

\section{REFERENCES:}

1. Cabinet of Ministers of Ukraine (2018) Resolution "National Transport Strategy of Ukraine until 2030". Available at: https://zakon.rada.gov.ua/laws/show/430-2018-\%D1\%80 (accessed 14 August 2021).

2. Bohachenko M.V. (2018) Teoretychni aspekty formuvannia taryfnoi polityky miskoho pasazhyrskoho transportu [Theoretical aspects of formation of tariff policy of city passenger transport]. Naukovyi visnyk Uzhhorodskoho natsionalnoho universytetu. Seriia: Mizhnarodni ekonomichni vidnosyny ta svitove hospodarstvo, vol. 19(1), pp. 19-22. Available at: http://nbuv.gov.ua/UJRN/Nvuumevcg_2018_19(1)_6 (in Ukrainian)

3. Bohachenko M.V. (2017) Svitovyi dosvid orhanizatsii miskoho pasazhyrskoho transportu [World experience in the organization of urban passenger transport]. Biznes navihator, vol. 4-1, pp. 21-25. Available at: http://nbuv.gov.ua/ UJRN/bnav_2017_4-1_6 (in Ukrainian)

4. Lehkyi S.A. (2013) Obgruntuvannia napriamkiv marketynhovykh doslidzhen pry vstanovlenni taryfiv na perevezennia pasazhyriv avtomobilnym transportom [Substantiation of directions of marketing researches at establishment of tariffs for transportation of passengers by motor transport]. Ekonomika transportnoho kompleksu, vol. 22, pp. 142-147. Available at: http://nbuv.gov.ua/UJRN/ektk_2013_22_15 (in Ukrainian)

5. Nekrasova L.A. and Bohachenko M.V. (2020) Rozvytok vzaiemodii vsikh vydiv transportu na osnovi intehrovanoi taryfnoi systemy pasazhyrskykh perevezen [Development of interaction of all types of transport on the basis of the integrated tariff system of passenger transportations]. Prychornomorski ekonomichni studii, vol. 51, pp. 73-79. Available at: http://nbuv.gov.ua/UJRN/bses_2020_51_14 (in Ukrainian)

6. Savchenko L.A. (2017) Metodyka rozrakhunku taryfiv na posluhy pasazhyrskoho avtomobilnoho transportu [Methods of calculating tariffs for passenger road transport services]. Visnyk Natsionalnoho universytetu «Lvivska politekhnika». Dynamika, mitsnist ta proektuvannia mashyn i pryladiv, no. 866, pp. 230-233. Available at: http://nbuv.gov.ua/UJRN/VNULPDM_2017_866_42 (in Ukrainian)

7. Sokulskyi O.Y., Haidai H.H. and Vasiltsova N.M. (2014) Ekonomiko-matematychne modeliuvannia pry vyznachenni taryfu pasazhyrskykh perevezen na marshrutakh iz urakhuvanniam yakosti obsluhovuvannia pasazhyriv [Economic and mathematical modeling in determining the tariff of passenger traffic on routes, taking into account the quality of passenger service]. Upravlinnia proektamy, systemnyi analiz i lohistyka, vol. 13. pp. 125-132. Available at: http://nbuv.gov.ua/UJRN/Upsal_2014_13\%282\%29_15 (in Ukrainian)

8. Pylypenko O.M. and Ohii O.V. (2018) Obgruntuvannia taryfu na perevezennia pasazhyriv avtobusnym transportom u m. Cherkasy [Substantiation of the tariff for transportation of passengers by bus transport in Cherkasy. Visnyk Cherkaskoho derzhavnoho tekhnolohichnoho universytetu. Seriia: Tekhnichni nauky, no. 2, pp. $20-25$. Available at: http://nbuv.gov.ua/UJRN/Vchdtu_2018_2_5 (in Ukrainian) 